\title{
Immobilization of Heavy Metals in Waste Phosphate Coating Sludge Using Kiln Dust as Portland Cement Substitute
}

\author{
G. Eker, V. Pinarli* \\ Department of Environmental Engineering, Uludag University, Turkey
}

Copyright(C2018 by authors, all rights reserved. Authors agree that this article remains permanently open access under the terms of the Creative Commons Attribution License 4.0 International License

\begin{abstract}
In the present study, stabilization and solidification (S/S) of the waste phosphate sludge (WPS) using Portland cement (PC) and cement kiln dust (CKD) was investigated. In the first place, only PC was used to stabilize 5, 10 and 15\% WPS. At a later stage, 10 and $15 \%$ CKD were used as PC substitute to stabilize 15\%WPS. WPS contained initially $130.2 \mathrm{mg} / \mathrm{L} \mathrm{Zn}$ and $22.6 \mathrm{mg} / \mathrm{L} \mathrm{Ni}$. U.S. Environmental Protection Agency (US-EPA) landfilling limits for $\mathrm{Zn}$ and $\mathrm{Ni}$ are $4.3 \mathrm{mg} / \mathrm{L}$ and $11 \mathrm{mg} / \mathrm{L}$, respectively. Setting times and unconfined compressive strength (UCS) values were measured and permeability of selected samples was determined. TCLP (Toxicity Characteristics Leaching Procedure) and SPLP (Synthetic Precipitation Leaching Procedure) were applied to determine the concentrations of $\mathrm{Zn}$ and $\mathrm{Ni}$ leached from the mortar samples and leachate $\mathrm{pH}$ values were measured. Use of the CKD as a cement substitute delayed setting times, decreased UCS and increased leached heavy metal concentrations. Leached $\mathrm{Zn}$ and $\mathrm{Ni}$ concentrations of the WPS stabilized with PC and CKD following SPLP were lower than the EPA landfilling limits. However, leached $\mathrm{Zn}$ concentrations following TCLP were not compatible with the EPA limit. Leached Ni concentrations remained lower than the EPA limit. It was concluded that relatively low levels of alkalies, $\mathrm{CaO}$ and $\mathrm{SiO}_{2}$ content of CKD negatively affected the setting, compressive strength and leaching characteristics.
\end{abstract}

Keywords Immobilization, Heavy Metals, Cement Kiln Dust

\section{Introduction}

Hazardous wastes are generally disposed in landfill after reduction of their toxicity [1]. Stabilization and solidification $(\mathrm{S} / \mathrm{S})$ process is one of the most common technologies to treat hazardous wastes before landfilling [2]. Portland cement (PC) is widely used as a binding agent for $\mathrm{S} / \mathrm{S}$ application to reduce toxic characteristics of waste. Alkalinity of the PC make it suitable to fix heavy metals in the form of hydroxides, silicates etc. compounds which are less soluble forms of the heavy metals [3-5]. S/S process allow the using several pozzolanic materials such as cement kiln dust (CKD), fly ash, blast furnace slag, silica fume etc. as a cement substitute [2,6,7]. CKD is a by-product obtained from cement factories and thousands tons of it are disposed annually by cement companies [8].

Several researchers focused on the effect of the CKD to the cement hydration properties and S/S process [9-12]. Harthy et al. investigated the effect of $5-30 \%$ CKD substitution to strength development. It was noted that UCS results decreased with CKD replacement [11]. Alem et al. researched the role of CKD substitution in setting process of the cement and results showed that setting times decreased with using of CKD [10]. Furthermore, CKD can positively affect the hydration process and heavy metal fixation depends upon the chemical characteristics. It was reported that UCS results of the waste stabilized with PC and CKD were higher than the results of waste dust stabilized with only PC [12]. Leaching results of heavy metals such as $\mathrm{Cd}, \mathrm{Cr}$ and $\mathrm{Pb}$ leaching results also showed that $\mathrm{CKD}$ was successful in reducing waste toxicity.

Effectiveness of the PC and CKD in S/S application are evaluated with the setting times, permeability, UCS and leaching tests etc. [2]. Setting time represents the beginning of the hardening process of the cement $[2,13]$. Measurement of the UCS shows the ability of the stabilized wastes to withstand overburden loads [14]. Permeability refers to the resistance of the material to the passage of water [15]. Leaching characteristics of the stabilized wastes are assessed by Toxicity Characteristics Leaching Procedure (TCLP) and Synthetic Precipitation Leaching Procedure (SPLP) which are proposed by USEPA for hazardous waste. TCLP and SPLP simulate landfilling 
condition and acid rain, respectively. Waste stabilized and solidified with binder can be determined as hazardous or non-hazardous according to concentrations of leached heavy metals [16-18].

Bursa is one of the large industrial cities in Turkey and automobile manufacturing is a major sector in the city. Waste phosphate sludge (WPS) is a residue from the phosphate coating process in automobile manufacturing industry. It is determined as a hazardous waste according to European Waste Catalog [19]. In one of the previous studies phosphate coating sludge was solidified using calcium aluminate cement [20]. It was noted that leaching results of the $15 \%$ WPS stabilized using only PC were higher than the EPA landfilling limits [21]. The aim of the present study was to investigate the effectiveness of the CKD as Portland cement substitute to reduce the toxic heavy metal concentrations of the $\mathrm{S} / \mathrm{S}$ product containing $15 \%$ WPS. Evaluation was made according to leaching results compared to EPA landfilling limits [18]. Additionally, the influence of CKD substitution on the setting times and UCS of the samples were reported and discussed.

\section{Experimental Work}

Raw WPS was received from an automobile industry. WPS is produced during phosphate coating process which prevents corrosion of metal surface. WPS was dried in an oven at $105^{\circ} \mathrm{C}$ for 24 hours before use. Ordinary PC was used as a main binder and CKD was used as a PC subsititute. The materials were obtained from the cement factory of Bursa. Moisture of the WPS was measured with Ohaus-MB200 machine. Specific surface areas of the WPS, $\mathrm{PC}$, and CKD were measured by the Blaine apparatus Tonic Technic 72071. The $\mathrm{pH}$ values were measured using a HACH 54650 - 18 Sension 156 pH Meter. Specific gravity of the WPS, PC and CKD were measured by Multi Pycnometer-Quantachrome VP/11497101401. Chemical composition of the WPS was determined with X-Ray Spectrophotometer XEPOS/76004814 and composition of $\mathrm{PC}$ and $\mathrm{CKD}$ were determined with X-Ray Spectrophotometer ARL 8660. Chemical composition and physical properties of Portland cement, cement kiln dust and waste phosphate sludge were given in Table 1.

Paste and mortar samples were prepared. Water-to-solid ratio was chosen as 0.5. Rilem Cembureau Standard Sand was used in the mortar samples according to ASTM C 778-87. Setting times of the pastes were determined using Vicat needle apparatus. After being removed from their molds, the mortar samples were cured by immersion in water. Mortar samples cast in square prismatic mortar molds with internal dimensions of $(40 \times 40 \times 160) \mathrm{mm}$. UCS values were determined using an ESEL ESL.25.001.B-015 $250 \mathrm{kN}$ compression machine after curing periods of 3, 7, 28,56 , and 90 days. Stress controlled loading speed setting of $0.05 \mathrm{kN} / \mathrm{sec}$ was applied for compression testing. Permeability of WPS solidified with PC was determined according to falling-head permeability method after 28 days of cure. The mortar samples were subjected to Toxicity Characteristics Leaching Procedure (TCLP) using an extraction fluid with $\mathrm{pH} 2.8$ at end of the 28 days. Synthetic Precipitation Leaching Procedure (SPLP) intended to simulate precipitation was also applied using an extraction fluid with $\mathrm{pH}$ 4.2. Leachate $\mathrm{pH}$ values were measured following TCLP and SPLP extractions. Leached $\mathrm{Zn}$ and $\mathrm{Ni}$ concentrations were measured using Bausch \& Lomb ARL/3520 AES Inductively Coupled Plasma (ICP).

Table 1. Chemical composition and physical properties of Portland cement, cement kiln dust and waste phosphate sludge

\begin{tabular}{|c|c|c|c|}
\hline & $\mathrm{PC}$ & CKD & WPS \\
\hline $\mathrm{CaO}(\%)$ & 65.41 & 43.60 & 0.02 \\
\hline $\mathrm{SiO}_{2}(\%)$ & 20.43 & 12.52 & 0.18 \\
\hline $\mathrm{Al}_{2} \mathrm{O}_{3}(\%)$ & 5.71 & 4.16 & 0.59 \\
\hline $\mathrm{Fe}_{2} \mathrm{O}_{3}(\%)$ & 3.45 & 2.53 & 22.98 \\
\hline $\operatorname{MgO}(\%)$ & 0.77 & 0.54 & 0.11 \\
\hline $\mathrm{P}_{2} \mathrm{O}_{5}(\%)$ & 0.12 & 0.071 & 31.70 \\
\hline $\mathrm{SO}_{3}(\%)$ & 2.43 & 0.34 & 0.01 \\
\hline $\mathrm{Na}_{2} \mathrm{O}(\%)$ & 0.42 & 0.34 & 0.79 \\
\hline $\mathrm{K}_{2} \mathrm{O}(\%)$ & 0.45 & 0.27 & 0.11 \\
\hline $\mathrm{Cl}^{-}(\%)$ & 0.01 & 0.01 & 0.03 \\
\hline LOI (\%) & 1.35 & 34.2 & 3.76 \\
\hline $\mathrm{ZnO}(\%)$ & - & - & 11.17 \\
\hline $\mathrm{NiO}(\%)$ & - & - & 0.58 \\
\hline Moisture (\%) & - & - & 75 \\
\hline $\mathrm{pH}$ & 13 & 11 & 3.8 \\
\hline Specific gravity $\left(\mathrm{g} / \mathrm{m}^{3}\right)$ & 2.6 & 2.7 & 2.6 \\
\hline Specific surface area $\left(\mathrm{cm}^{2} / \mathrm{g}\right)$ & 3416 & 4222 & 3406 \\
\hline
\end{tabular}

\section{Results and Discussion}

WPS was identified as hazardous waste in the European Waste Catalogue, with the code number of 110108 because of the high $\mathrm{Zn}$ and Ni concentrations. WPS contained $75 \%$ moisture as due to the wet conditions of phosphate coating bath. Heavy metal content of the WPS was measured as $130.2 \mathrm{mg} / \mathrm{L} \mathrm{Zn}$ and $22.6 \mathrm{mg} / \mathrm{L} \mathrm{Ni}$. To be disposed safely in landfills according to the USEPA, $\mathrm{Zn}$ and $\mathrm{Ni}$ concentrations of the sludge should be lower than $4.3 \mathrm{mg} / \mathrm{L}$ and $11 \mathrm{mg} / \mathrm{L}$, respectively [18]. Chemical composition and physical properties of the PC, CKD and WPS were determined. Major constituents of the $\mathrm{PC}$ and $\mathrm{CKD}$ were $\mathrm{CaO}, \mathrm{SiO}_{2}, \mathrm{Al}_{2} \mathrm{O}_{3}$ and $\mathrm{Fe}_{2} \mathrm{O}_{3}$. Alkali content of $\mathrm{PC}$ was higher than the CKD's. Furthermore, CKD has a relatively low $\mathrm{Na}_{2} \mathrm{O}, \mathrm{K}_{2} \mathrm{O}$ and $\mathrm{SO}_{3}$ content compared to the literature values up to $1.0 \%, 5.9 \%, 16.7 \%$, respectively [22]. Specific gravity of the PC, CKD and WPS were similar, $\mathrm{pH}$ of the 
$\mathrm{PC}$ and $\mathrm{CKD}$ were higher than $\mathrm{pH}$ of the WPS.

\subsection{Setting Times of the Paste Samples Containing WPS, PC and CKD}

Setting times were shown in Figure 1. Initial and final setting times increased with increasing WPS content. The results were longer than the setting times of the PC (as reference sample without WPS) measured as 80 minutes (initial) and 165 minutes (final). It was attributed to the retardation effect of $\mathrm{Zn}(9.0 \%)$ and $\mathrm{P}_{2} \mathrm{O}_{5}(31.7 \%)$ content of WPS $[2,5,23]$.
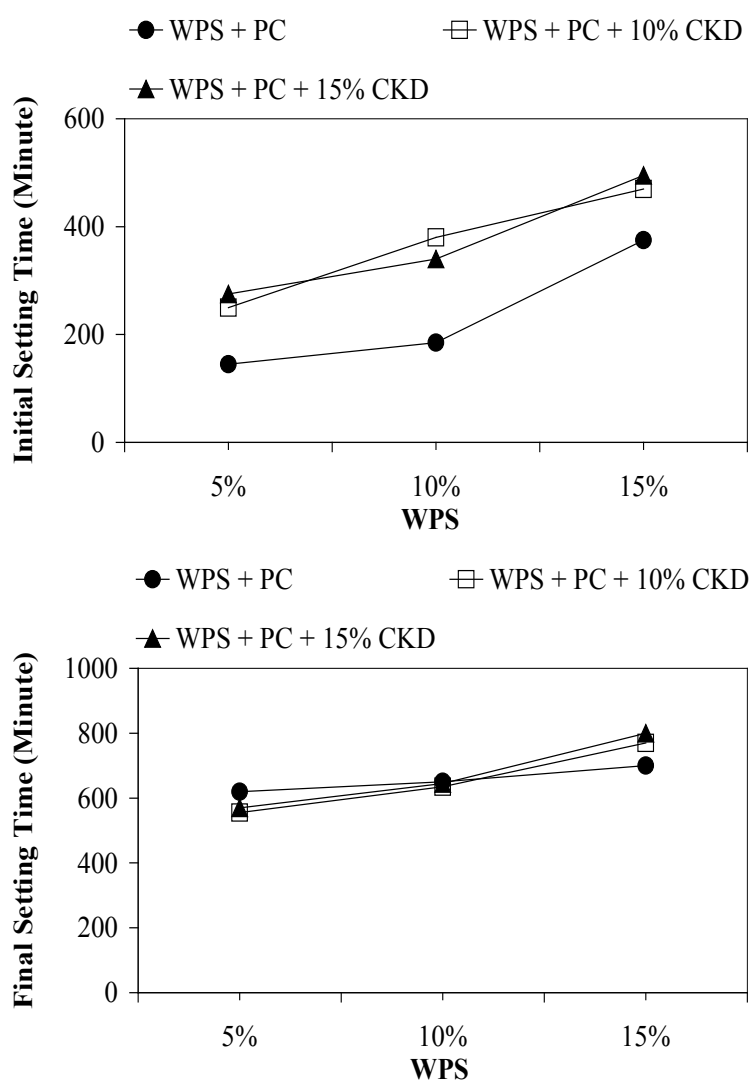

Figure 1. Setting times of the pastes containing waste phosphate sludge (WPS), Portland cement (PC) and cement kiln dust (CKD)

Initial setting times of paste samples were increased with using of CKD as cement substitute. Cement particles may have been coated by not only WPS but also by CKD at the beginning of the setting process. As a result, initial reactions between cement particles and water retarded. Formation of the first hydration products and then breaking of the layer delayed. Final setting time results of the paste sample containing 5\% WPS was slightly decreased with CKD substitution. High specific surface area of the CKD may have contributed to acceleration of setting process by means of increased interaction with water [2]. Furthermore, it was thought that $5 \%$ WPS did not inhibite pozzolanic reactions. Final setting delayed with the using CKD to stabilize increased amount of WPS. CKD contained $0.2 \%$ $\mathrm{K}_{2} \mathrm{O}$ and $0.3 \% \mathrm{Na}_{2} \mathrm{O}$ by weight. The alkali content of the
CKD was much lower than that of reported in the literature $[2,12]$. Retardation of setting process was attributed to low alkali content of the CKD. It is known that alkali $\left(\mathrm{Na}_{2} \mathrm{O}\right.$ and $\mathrm{K}_{2} \mathrm{O}$ ) salts contribute to the raise in $\mathrm{pH}$, inhibit the formation of $\mathrm{CaSO}_{4}$ and as a result, accelerate setting process $[10,24,25]$.

\subsection{Unconfined Compressive Strength Results of the Mortar}

UCS values at the end of the $3,7,28,56$ and 90 curing days are shown in Figure 2. UCS results of the mortar samples containing 15\% WPS and $85 \%$ PC were lower than the results of the reference sample. Phosphate and zinc precipitates which coat the surface of cement grains as a layer might have formed, thus preventing the hardening process $[21,26,27]$.

UCS values of the WPS stabilized with PC and $10 \%$ CKD as a cement substitute were not lower than the results of WPS stabilized with only PC. However, UCS results were decreased with increasing amount of the CKD substitution from $10 \%$ to $15 \%$. Retardation of setting can affect the UCS results during the early curing ages [27] Decreases in UCS results were attributed to lower $\mathrm{CaO}$ $(43.60 \%)$ and $\mathrm{SiO}_{2}(12.5 \%)$ content of the CKD than content of $\mathrm{PC}\left(\mathrm{CaO}: 65.4, \mathrm{SiO}_{2}: 20.4\right)$. It is known that these components constitute $\mathrm{C}_{3} \mathrm{~S}$ which is one of the important phases responsible for strength development after set [2].

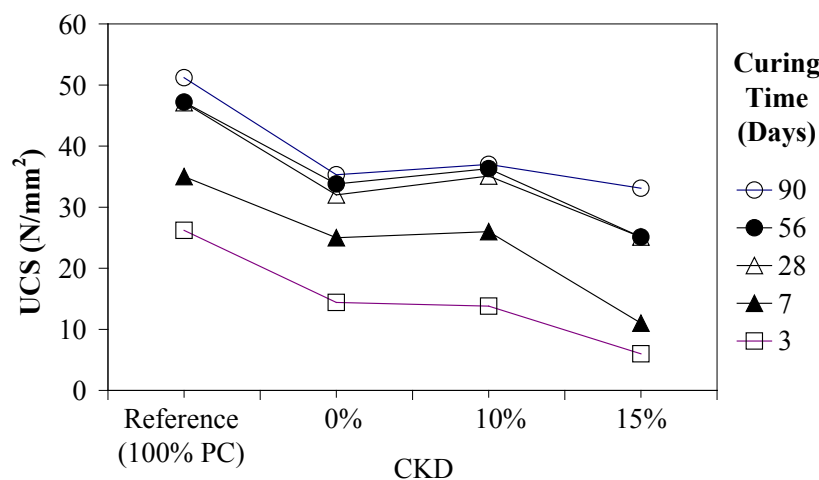

Figure 2. Unconfined compressive strength (UCS) values of the mortar samples

\subsection{Relationship between Unconfined Compressive Strength and Permeability}

Permeability was increased while UCS was decreased with increasing of the WPS ratios as shown in Figure 3. Results indicated that there was an adverse relation between UCS and permeability. 5\% WPS stabilized with PC was defined as non-permeable material (permeability $<10^{-8} \mathrm{~cm} / \mathrm{sec}$ ) and other samples containing $10-15 \%$ WPS were defined as a semi-permeable materials. EPA requires permeability values less than $10^{-7} \mathrm{~cm} / \mathrm{sec}$ to safely dispose in landfill [28]. Result of 5\% WPS stabilized 
with PC was in accordance with EPA value.

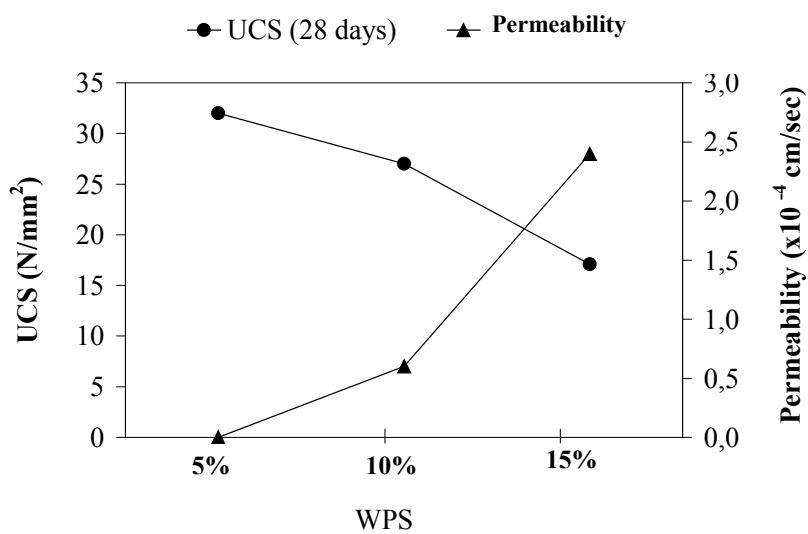

Figure 3. Relationship between unconfined compressive strength (UCS) and permeability of waste phosphate sludge (WPS) solidified with Portland cement

\subsection{Leaching Results of Mortar Samples}
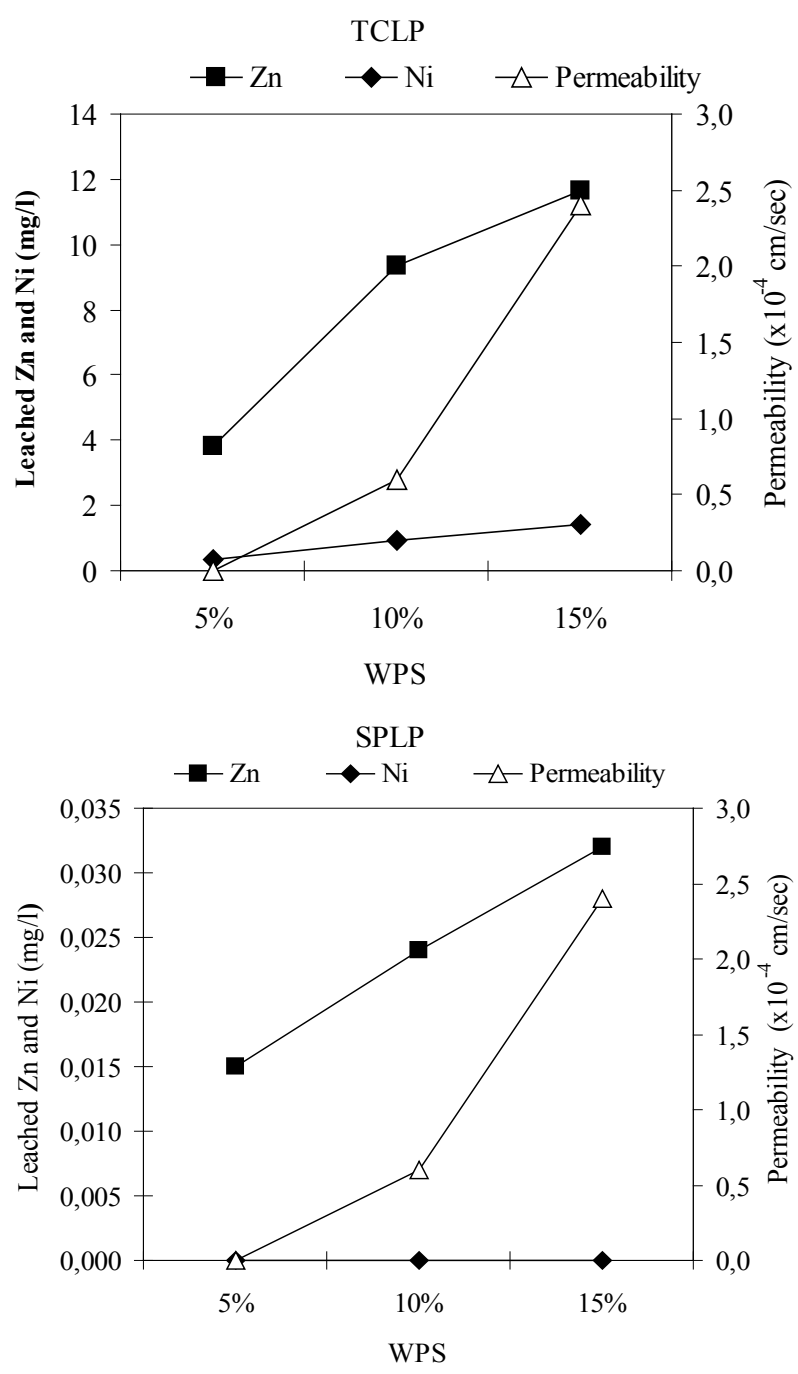

Figure 4. Relationship between heavy metal leaching following leaching and permeability of waste phosphate sludge (WPS) solidified with Portland cement a) TCLP b) SPLP
Relationship between leaching and permeability: Relation between leached heavy metal concentrations and permeability results of the WPS stabilized with only PC are shown in Figure 4a (TCLP) and Figure 4b (SPLP). Following TCLP and SPLP extractions, leaching of $\mathrm{Zn}$ and $\mathrm{Ni}$ increased with increasing of the permeability. It was showed that permeability of the $\mathrm{S} / \mathrm{S}$ product was an important factor, as it indicated transport of contaminants from stabilized waste to the environment.

Role of CKD in heavy metal fixation: Fixation of $\mathrm{Zn}$ and $\mathrm{Ni}$ decreased with using of CKD as a cement substitute. $91 \% \mathrm{Zn}$ and $94 \% \mathrm{Ni}$ were fixed in $15 \%$ WPS stabilized with only PC. Fixation ratios were decreased to $87 \% \mathrm{Zn}$ and $91 \% \mathrm{Ni}$ with $15 \% \mathrm{CKD}$ used as PC substitute. Leached heavy metal concentrations increased with increasing amount of CKD (Figure 5). Leached Zn concentrations remained above the EPA landfilling limit. However, Ni concentration conformed to the EPA limit. Inefficiency of the $\mathrm{CKD}$ was due to its lower $\mathrm{CaO}, \mathrm{SiO}_{2}$ and alkali content comparing with PC. Relatively low amount of alkali components reduce formation of hydrate products which support high specific surface area to fixation of heavy metals. Furthermore, low amount of $\mathrm{CaO}$ and $\mathrm{SiO}_{2}$ in the mixture mean that less amount of $\mathrm{C}_{3} \mathrm{~S}$ phase is formed which is required for $\mathrm{Zn}$ fixation [12,29]. In the present study, decrease in the amount of these constituents probably reduced the amounts of the hydration products, WPS also might be interacted with PC-CKD reactions.

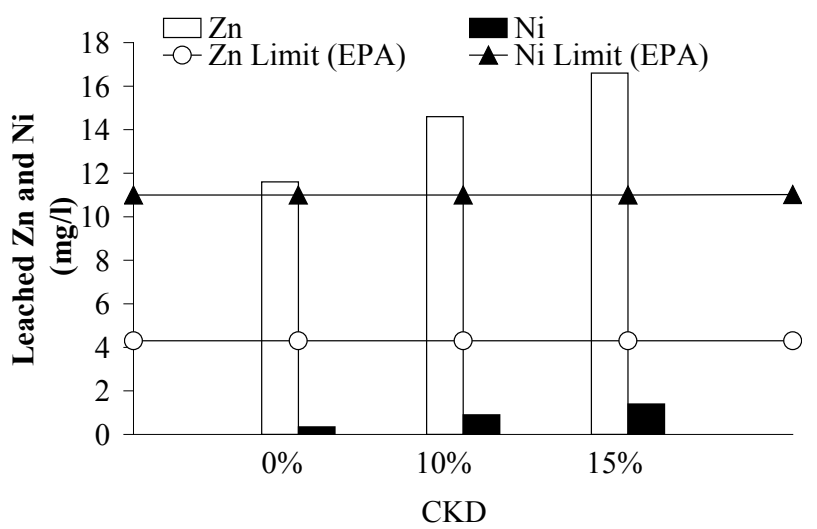

Figure 5. Zinc and nickel leached from the $15 \%$ waste phosphate sludge solidified with Portland cement and cement kiln dust (TCLP)

TCLP and SPLP results: Leached heavy metal concentration increased as the $\mathrm{pH}$ values decreased. It was seen that the leachabilities of the metals were $\mathrm{pH}$ dependent. Leachate $\mathrm{pH}$ following TCLP decreased from 5.2 to 4.8 when CKD used as cement substitute and the solubility of $\mathrm{Zn}$ and $\mathrm{Ni}$ increased. Low $\mathrm{pH}$ values were attributed to the relatively low alkali content of CKD. Results indicated that PC substitution by CKD reduced the alkaline nature of the system. $\mathrm{Zn}$ concentrations leached from S/S products after SPLP extraction were not higher than $0.2 \mathrm{mg} / \mathrm{L}$. This value conformed with the EPA landfilling limit. 


\section{Conclusions}

The following conclusions may be drawn from this study:

- $\quad$ Setting time prolonged as CKD ratios in the sample increased. Possible reason of retardation was relatively low alkali content of the CKD.

- $\quad$ Permeability of the mortar samples increased as the UCS decreased. It was found that the more permeable stabilized products had lower UCS. Also, leached $\mathrm{Zn}$ and $\mathrm{Ni}$ increased with permeability.

- UCS results were decreased with increasing CKD substitution ratio from $10 \%$ to $15 \%$. Lower $\mathrm{CaO}$ and $\mathrm{SiO}_{2}$ content of the $\mathrm{CKD}$ with respect to $\mathrm{PC}$ negatively affected the strength development.

- $\quad$ Leached Zn and Ni concentrations increased with CKD substitution.

- TCLP results showed that the leached $\mathrm{Ni}$ concentrations were lower than the EPA landfilling limits. However, the leached $\mathrm{Zn}$ concentrations were higher.

- $\quad$ Leached $\mathrm{Zn}$ and Ni concentrations following SPLP extraction were lower than the EPA limits.

Relatively low levels of alkalies, $\mathrm{CaO}$ and $\mathrm{SiO}_{2}$ content of CKD negatively affected the setting, hardening and leaching processes. It can be concluded from the results of the present study that the required degree of stabilization of $15 \%$ WPS using CKD as a PC substitute was not achieved. Using other pozzolanic materials for WPS stabilization may be investigated in further studies.

\section{REFERENCES}

[1] Lagrega, M.D., Buckingham P.L. and Evans J.C. 1994. Hazardous Waste Management. King, P. H., Eliassen, R. Mc Graw-Hill. New York. USA.

[2] Conner J.R. 1990. Chemical Fixation and Solidification of Hazardous Wastes, Chapter 10: Portland Cement-based systems and Chapter 14: Kiln dust and fly ash-based processes, ISBN:0-442-20511-2, Van Nostrand Reinhold: $115^{\text {th }}$ Fifth Avenue, New York 10003

[3] Vyšvaĝil, M., Bayer, P. 2016. Immobilization of heavy metals in natural zeolite-blended cement pastes Procedia Engineering 151, 162-169.

[4] Ucaroglu S., Talinli, İ. 2012. Recovery and safer disposal of phosphate coating sludge by solidification/stabilization, Journal of Environmental Management, 105, 131-137.

[5] Glasser F.P. 1997. Fundamental aspects of cement solidification and stabilization. J. Hazard. Mater. 52, $151-170$

[6] Siddique, R. 2006. Utilization of cement kiln dust (CKD) in cement mortar and concrete. An Overview. Resour. Conserv. Recy. 48(4), 315-338.
[7] Singh, M., Garg, M. 1999. Cementitious binder from fly ash and other industrial wastes. Cement Concrete Res. 29, 309-314.

[8] Udoeyo, F. F., Hyee, A. 2002. Strengths of cement kiln dust concrete. Technical Note J. Mater. Civil Eng. 14, 524-526

[9] Mortula, M., Gibbons, M., Gagnon, GA. 2007. Phosphorus adsorption by naturally-occurring materials and industrial by-products, Journal of Environmental Engineering and Science, 6(2), 157-164.

[10] Alem, S.A., Aziz, M.A., Heikal, M., Didamony, H. 2005. Effect of cement kiln dust substitution on chemical and physical properties and compressive strength of Portland and slag cement. Arab. J. Sci. Eng., 30, 263-273.

[11] Harthy, A.S., Taha, R., Maamary F.A. 2003. Effect of cement kiln dust (CKD) on mortar and concrete mixtures. Constr.Build. Mater, 17, 353-360.

[12] Park, C.K. 2000. Hydration and solidification of hazardous wastes containing heavy metals using modified cementitious materials. Cement Concrete Res., 30, 429-435.

[13] Kondo R.L., Diamon M. J.F.A. 1972. Review of Mechanisms Set-Retardation In Portland Cement Pastes Containing Organic Admixtures. Cement Concrete Res. 2 , 415-433.

[14] Barth, E.W. 1990. Stabilization and Solidification of Hazardous Wastes. Noyes data Corporation, Park Ridge, New Jersey, U.S.A.

[15] EPA, U.S. Environmental Protection Agency (1989). Stabilization and solidification of CERCLA and RCRA wastes, physical tests, chemical testing procedures, Technology screening, and field activities. EPA/625/6-89/022; p. 4.11.

[16] Hu, L.F., Long Y.Y., Shen D.S. 2016. Comparison of the Stabilizing Capabilities of Iron and Aluminum in Treating Waste Highly Contaminated with Arsenic, Environmental Engineering and Management Journal, 15 (2), 349-356.

[17] Erdem M., Özverdi A. 2011. Environmental risk assessment and stabilization/solidification of zinc extraction residue: II. Stabilization/solidification, Hydrometallurgy, 105, 270276.

[18] EPA, U.S. Environmental Protection Agency 1999. Land Disposal Restrictions Phase II- Universal Treatment Standards, and Treatment Standards for Organic Toxicity Characteristics Wastes and Newly Listed Wastes, Final Rule, Title 40 Federal Regulations (CFR), 7-1-99 Edition, Part 268.

[19] DOCE, European Waste Catalogue 2001. L226/3-24. 2000/532/EC, Commission Decisions 2001/118/EC, 2001/119/EC and Council Decision 2001/573/EC.

[20] Navarro-Blasco I., Duran A., Perez-Nicolas M., Fernandez J.M., Sirera R., Alvarez J.I. 2015. A safer disposal of hazardous phosphate coating sludge by formation of an amorphous calcium phosphate matrix, Journal of Environmental Management 159, 288-300.

[21] Pinarli, V., Karaca, G., Salihoğlu, G., Salihoğlu, N.K. 2005. Stabilization and solidification of waste phosphate sludge using Portland cement and fly ash as cement substitute. $J$. 
Environ. Sci. Heal. A. 40, 1763-1774

[22] Gdoutos, M.S.K., Shah, S.P. 2003. Hydration and properties of novel blended cements based on cement kiln dust and blast furnace slag. Cement Concrete Res., 33, 1269-1276.

[23] Cheeseman, C.R., Asavapisit, S., Knight, J. 1998. Effect of uniaxially pressing ordinary Portland cement pastes containing metal hydroxides on porosity, density, and leaching. Cement Concrete Res. 28, 1639-1653

[24] Stegemann J. A. 2005. Interactions between wastes and binders. In R. D. Spence and C. Shi Eds., Stabilization and Solidification of Hazardous, Radioactive and Mixed Wastes. CRC Press, USA, pp. 151-176.

[25] Heikal, M., Aiad, I., Helmy, I.M. 2002. Portland cement clinker, granulated slag and bypass cement dust composites. Cement Concrete Res., 32, 1805-1812.
[26] Li, X.D., Zhang, Y.M., Poon, C.S., Lo, I.M.C. 2001. Study of zinc in cementitious material stabilized/solidified wastes by sequential chemical extraction and microstructural analysis. Chemical Speciation and Bioavailability 13, 1-7.

[27] Bhatty, J.B. And West, B.P. 1996. Stabilization and Solidification of Hazardous, Radioactive and Mixed Wastes. 3rd Volume, ASTM STP 1240 Wastes, p.147-159.

[28] Perera, A.S.R., Tabbaa, A., Reid, J.M., Stegemann, J.A. And Shi, C. 2005. Testing and performance criteria for stabilized/solidified waste forms. In R. D. Spence, C. Shi Eds., Stabilization and Solidification of Hazardous, Radioactive and Mixed Wastes. CRC press, USA. pp. 302.

[29] Bhatty, M. S. Y. 1987. Fixation of metallic ions in Portland cement. Superfund'87, Proceedings of the 4th National Conference on Hazardous Wastes and Hazardous Materials (PCA \& D Serial No. 1834), Washington DC, p.140-145. 